\title{
Superoxide Dismutase Expression in the Ovaries of Periodontitis Animal Models Induced by Porphyromonas gingivalis and Treated with Cassava Leaves Extract
}

\author{
Agustin Wulan Suci-Dharmayanti ${ }^{1 *}$, Ajeng Nurwahyuningtyas Anjani ${ }^{2}$, Ari Tri Wanodyo \\ Handayani $^{3}$, Zahreni Hamzah ${ }^{1}$, Zahara Meilawaty ${ }^{1}$, Masniari Novita ${ }^{1}$, Mei Syafriadi ${ }^{1}$, \\ Amandia Dewi Permana Shita ${ }^{1}$
}

\section{KEYWORDS}

Cassava Leaves Extract, Ovarian, P. gingivalis, Superoxide dismutase (SOD)

\section{ABSTRACT}

The ovaries represent the female reproductive organs that determine the women's fertility status and their systemic and oral health, correlating to sex steroid hormone alteration. This study aimed to investigate the effect of cassava leaves extract treatment to SOD expression in the animal model-ovaries after Porphyromonas gingivalis injection. 15 female Sprague Dawley rats were used and divided into five groups: (1) control without cassava leaves extract treatment (C); (2) P. gingivalis without cassava leaves extract treatment (T1); (3) P. gingivalis and cassava leaves extract (T2); (4) P. gingivalis and vitamin C (T3); and (5) P. gingivalis and metronidazole (T4). Animal were euthanised at day seven after the initial treatment to collect ovaries. The ovaries sections were immunohistochemically stained to quantify SOD expression using light microscope while the Image J software was used to quantify the SOD expression. The results showed that all of the follicle types had the same intensity of SOD expression. Most of the follicles exhibited low intensity of SOD expression, except for atretic follicles. In conclusion, P. gingivalis and cassava leaves extract influenced SOD expression in the ovaries of animal models, which increased the SOD expression.

\section{INTRODUCTION}

The ovaries represent the female reproductive organs that determine the women's fertility status. This fertility is closely related to folliculogenesis or the follicles growth and development process in the ovaries [1]. According to the global burden of diseases data, female infertility increased $15.0 \%$ from 1990 to 2017 , or the infertility showed a shift of $0.4 \%$ per year. Premature menopause or premature ovarian aging can induce infertility [2].

\footnotetext{
${ }^{1}$ Biomedical Department, Faculty of Dentistry, Universitas Jember, Indonesia.

${ }^{2}$ Faculty of Dentistry, Universitas Jember, Indonesia.

${ }^{3}$ Dental Public Health Department, Faculty of Dentistry, Universitas Jember, Indonesia.

*Correspondence: agustinwulan.fkg@unej.ac.id
}

The increase in incidence results in a decrease of the birth rate globally, and affects the systemic condition as well as the oral health condition $[3,4,5]$. In this case, the systemic and oral health correlates to sex steroid hormone alteration, where the hormones are involved in the body's metabolic processes, including maintaining the integrity of oral health and diversity of the oral microbiome $[6,7]$.

Moreover, hormonal imbalance increases oral bacteria's virulence, especially Porphyromonas gingivalis, and triggers oral tissue diseases, such as periodontitis. Several studies suggested that periodontitis is correlated to hormonal alteration, especially in female reproductive organ function in menopause and pregnancy $[3,4,7]$. Several studies described a bidirectional relationship between female reproductive organ function and 
periodontitis, although the mechanism of this relationship is still unclear $[8,9]$. Our unpublished preliminary study also indicated that $P$. gingivalis infection stimulated sex hormone changes and systemic inflammation.

These hormonal changes due to $P$. gingivalis infection results in an oxidative stress due to a reduced Superoxide Dismutase (SOD) activity. Hormonal changes and $P$. gingivalis toxin reduce the level and activity of endogenous SOD, thereby causing oxidant-antioxidant imbalance and triggering oxidative stress. Moreover, a decrease or fluctuation in oestrogen level decreases the expression of the SOD gene. If the alteration of oestrogen level continues for a long time, it will decrease the level and activity of SOD [10].

P. gingivalis inflammation activates neutrophils to produce toxic substances such as free radicals. These substances that aim to kill bacteria can also attack the molecules around the area of inflammation. As what happens with the imbalance of oestrogen level, the excessive free radicals induced by $\mathrm{P}$. gingivalis stimulates oxidative stress [11].

This condition requires antioxidants to balance the oxidants level in the body. Antioxidants are the chemical compound or agents which in a certain amount is able to inhibit and prevent cell destruction caused by excessive oxidant or oxidant process $[12,13]$. Several plants contain antioxidant ingredients, such as cassava leaf from the plant Manihot esculenta $C$. The bioactive components that are present in Cassava leaves are flavonoids, alkaloids, tannins, anthraquinones, saponins, reduced sugars and anthocyanidins [13]. This study aimed to investigate the effect of cassava leaves extract treatment on SOD expression in the rat ovaries after $P$. gingivalis injection. This study also identified SOD expression in each follicle type, such as primary, secondary, tertiary and atretic follicles, after $P$. gingivalis injection.

\section{MATERIALS AND METHODS}

This study involved female Sprague Dawley rats as animal models. All of the procedures had obtained approval from the Ethics and Advocacy Committee of Faculty of Dentistry, Gadjah Mada University (00354 / KKEP / FKG-UGM / EC / 2020). The criteria of animal models were as follows: healthy, 8-10 weeks old, with $200-250$ gr body weight, and had never been used for previous studies.

\section{Cassava leaves extract preparation}

Cassava leaves (Manihot esculenta C.) were obtained from Jember District, East Java Province, Indonesia. The cassava leaves chosen needed to meet these criteria: intact and was the fifth leaves from the top of the tree. Cassava leaves extract was prepared by maceration method. Briefly, $450 \mathrm{~g}$ of cassava leaves were removed from the stem and aerated without sun exposure for three days at the room temperature. The dry leaves were cut into small pieces and sieved using an 80-maze sieve to obtain a fine powder. The fine powder of cassava leaves was subsequently macerated with $96 \%$ ethanol (250g:1.5L)). It was stirred twice every 24 hours. The solution was concentrated with a rotary evaporator at $50^{\circ} \mathrm{C}$ and $90 \mathrm{rpm}$ until the solution was semi-solid [15].

\section{Animal models preparation}

All animal models were adapted for a week before treatment, and they were given standard feed and drink ad-libitum. 15 Sprague Dawley rats were divided into five groups: 1 ) without any treatments (C); 2) P. gingivalis without treatment (T1); 3) P. gingivalis and treated with cassava leaves extract $(\mathrm{T} 2)$; 4) P. gingivalis and treated with vitamin C (T3); and 5) $P$. gingivalis and treated with metronidazole (T4).

The animal models in T2-T4 were as periodontitis model. For the periodontitis model, the animal models were injected with $5 \mathrm{mg} / 0.5 \mathrm{ml}$ PBS (Phosphate Buffer Saline) of P. gingivalis, in which the concentration was $2.10^{9} \mathrm{CFU} / \mathrm{ml}$, in the buccal and lingual gingival grooves of the lower left first molar. The injection was administered every three days for two weeks using a $30 \mathrm{G}$ tuberculin syringe [15].

After 14 days, the animal models (T2) were treated with $179.2 \mathrm{mg} / \mathrm{kg}$ BW cassava leaves extract orally, divided into two administrations $(2 \mathrm{ml}$ every administration at 8.00 AM and 8.00 PM) daily for a week [15]. Likewise, T3 and T4 were treated with vitamin C and metronidazole, respectively. Based on dose conversion, the dose of vitamin $C$ and metronidazole used was $2.25 \mathrm{mg} / \mathrm{kg}$ BW [16].

On day 8 , the animal models were euthanised and their ovaries were then removed. The ovaries were fixed by $40 \%$ formalin solution and prepared for histology preparation. The ovaries preparation was stained by immunohistochemistry staining using superoxide dismutase (SOD) marker. After that, the SOD expression was investigated and observed under a light microscope in 400x magnification and 
Image J software to calculate SOD percentage. The data were analysed using qualitative analysis [17].

\section{RESULTS}

SOD presents as an intracellular antioxidant that acts as a cell protector against excess oxidant and oxidative stress. Moreover, it prevents cell degeneration and injury, particularly in the ovaries. This study exhibited the antioxidant marker expression (SOD) in ovaries induced by $P$. gingivalis and treated cassava leaves extract.

Table 1 Intensity of SOD expression in ovaries of animal model

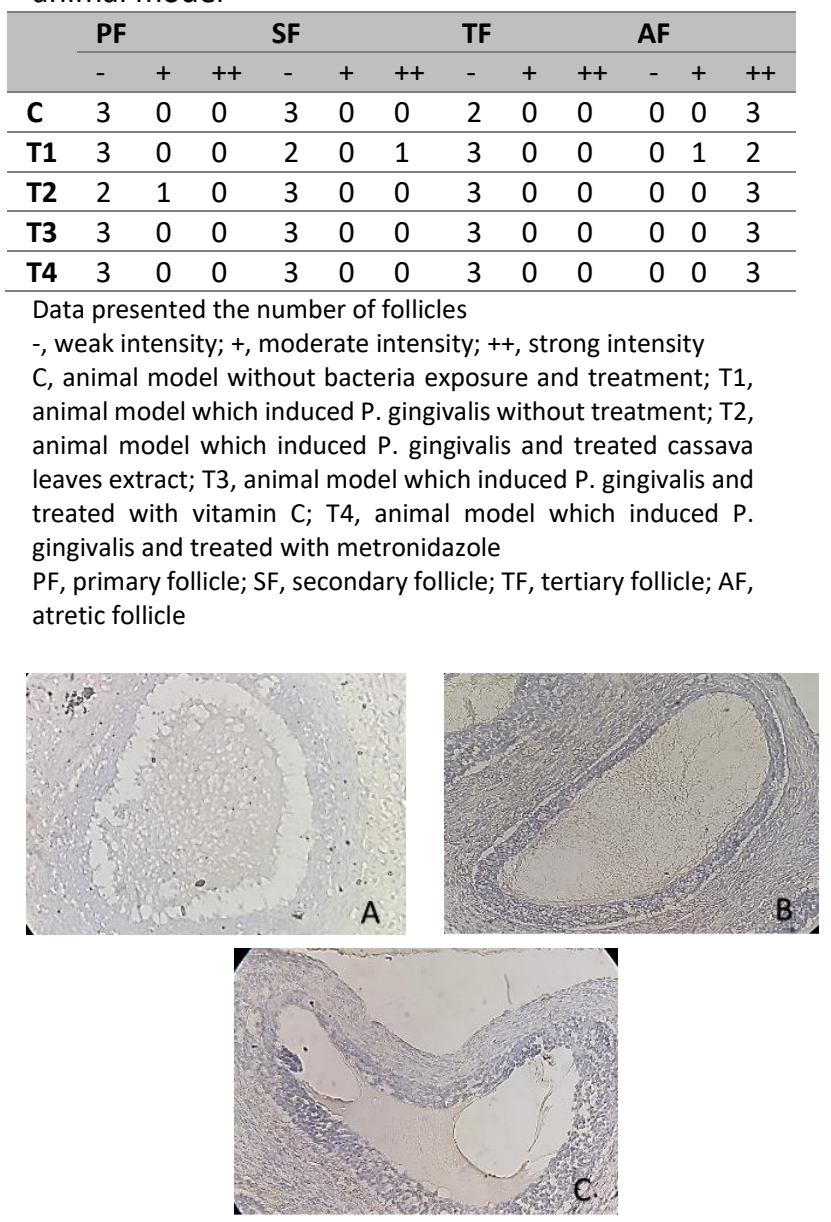

Figure 1 Intensity SOD expression in the ovaries of animal models in control and treatment groups. Observation was taken under light microscope by 400x magnification. A) weak intensity; B) moderate intensity; C) strong intensity

The ovary is one of the reproductive organs which represents the site for follicle cell development. Follicle's characteristic varies depending on their development stages, such as in the SOD expression in follicles. SOD expression depends not only on the development stage of follicles but also on the external environment, such as drug and external antioxidant usage. The figures and tables exhibited the SOD expression in ovary follicles, which was influenced by systemic exposure and treatment.

The observation exhibited the strength of SODexpression intensity. All of the groups showed the same intensity of SOD expression in all of the follicle types. Most of the follicles in the groups exhibited low intensity of SOD expression, except atretic follicles in all of the groups. T1 and T2 presented moderate intensity in the primary and secondary follicle, although only an animal model expressed it (Table 1 and Figure 1).

Table 2 Percentage of SOD expression in ovarian follicles of animal model

\begin{tabular}{cccccccccc} 
& \multicolumn{2}{c}{ PF } & \multicolumn{2}{c}{ SF } & \multicolumn{2}{c}{ TF } & \multicolumn{2}{c}{ AF } & Total \\
\cline { 2 - 10 } & $\mathrm{N}$ & $\%$ & $\mathrm{~N}$ & $\%$ & $\mathrm{~N}$ & $\%$ & $\mathrm{~N}$ & $\%$ & $\mathrm{~N}$ \\
\hline C & 0 & 0 & 0 & 0 & 1 & 14.3 & 6 & 85.7 & 7 \\
\hline T1 & 0 & 0 & 1 & 7.7 & 0 & 0 & 12 & 92.3 & 13 \\
\hline T2 & 1 & 5.3 & 0 & 0 & 0 & 0 & 18 & 94.7 & 19 \\
\hline T3 & 0 & 0 & 0 & 0 & 0 & 0 & 16 & 100 & 16 \\
\hline T4 & 0 & 0 & 0 & 0 & 0 & 0 & 13 & 100 & 13 \\
\hline
\end{tabular}

C, animal model without bacteria exposure and treatment; T1, animal model which induced $P$. gingivalis without treatment; $T 2$, animal model which induced $P$. gingivalis and treated cassava leaves extract; $T 3$, animal model which induced $P$. gingivalis and treated with vitamin C; T4, animal model which induced P. gingivalis and treated with metronidazole

$\mathrm{PF}$, primary follicle; SF, secondary follicle; TF, tertiary follicle; $\mathrm{AF}$, atretic follicle
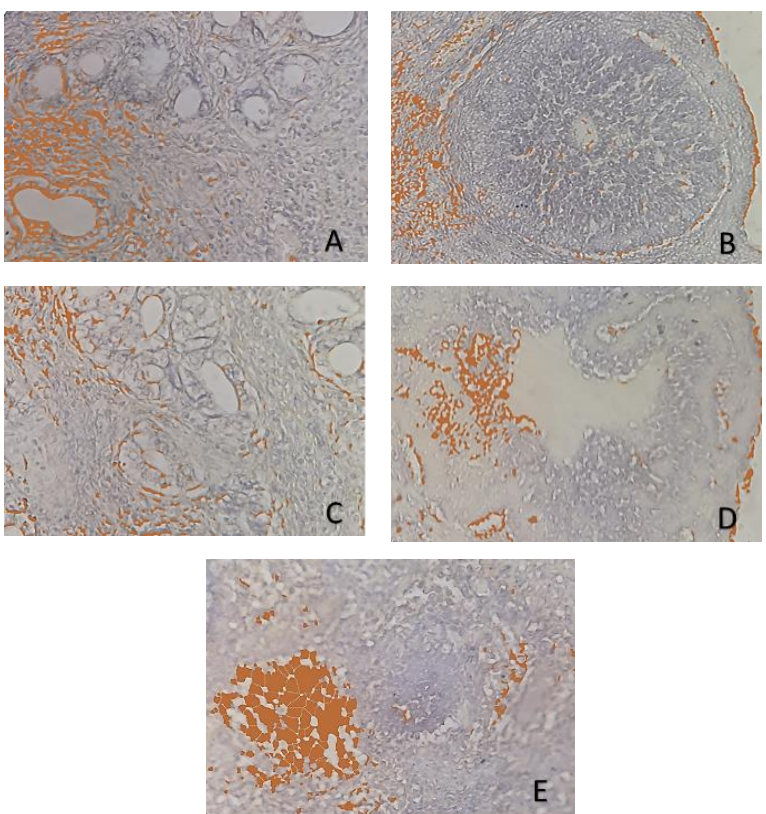

Figure 2 SOD expression in the ovaries of animal models in control and treatment groups. Observation was taken under light microscope by 400x magnification and analysed using Image-J software program; orange area indicated SOD expression. A) tertiary and atretic follicle of control group; B) secondary follicle of T1 group; C) primary and atretic follicle of T2; D) atretic follicle of T3; E) atretic follicle of T4 
Table 2 and Figure 2 represented the follicle found in the animal model and the follicle's percentage that expressed the SOD marker. Most of the follicles in all groups did not express SOD marker, and only atretic follicles expressed SOD marker. T3 and T4 exhibited the highest expression in atretic follicles. Therefore, less than $15 \%$ or only a follicle in control, $\mathrm{T} 1$, and $\mathrm{T} 2$ groups exhibited SOD expression.

In this study, interestingly, the ovary follicle atretic among the treatment groups, especially the group treated with cassava leaves extract (T2), was more than the other treatment groups and control group. Moreover, the number of atretic follicles in the T2 group was significantly higher than the animal model exposed P. gingivalis without treatment (T1).

\section{DISCUSSION}

The ovaries are physiologically dynamic organs due to the roles they play in the complex folliculogenesis cycles. Within the follicle, oocytes development depends on the granulosa cell and follicular fluid. The SOD enzyme activity represents one factor influencing the granulosa cells, follicular fluid, and follicular development $[18,19]$. This study showed that most of the atresia follicles expressed SOD markers, and their intensity was higher than the other follicles. It was probably due to the increased activity of the SOD enzyme, as an endogenous and exogenous antioxidant, in balancing the folliculogenesis process and preventing the granulosa cells' apoptosis due to $\mathrm{P}$. gingivalis infection. Lipopolysaccharide as a virulence factor of $\mathrm{P}$. gingivalis might induce inflammation and apoptosis of granulosa cells [19]. Several studies suggested that bacteria enhanced reactive oxygen species (ROS) production and oxidative stress, which induced folliculogenesis alteration $[18,20,21]$.

This study exhibited that the number of the atresia follicles in the groups induced by P. gingivalis and treatment agents were higher than in the group induced by P. gingivalis without treatment. Bacteria and treatment agents might cause the apoptosis of granulosa cells, which triggered antral follicles' development into atresia follicles. Although atresia follicles can occur in menstruation, ovaries follicles develop into atresia due to several factors, such as metabolic process alteration in the ovaries $[22,23]$. The herbal extract and drug usage stimulate metabolites accumulation in the ovaries. These metabolites affect the follicular fluid environment, and it impacts on folliculogenesis. Environment and nutrition in follicles trigger metabolism and genetic alteration in the follicular fluid and granulosa cells, which impair ovarian follicle development and Ann Dent UM. 2021, 28:40-46 trigger the atresia follicular development [19]. Several studies suggested that an alteration in the follicular fluid stimulated granulosa cells apoptosis. This follicular fluid plays a role in follicle development, oocyte maturation, and follicular atresia formation [19,22,23].

Moreover, the enzyme alkaline phosphatase activity and antioxidants physiologically control the environment and nutrition in the ovaries. Several studies revealed that alkaline phosphatase and antioxidant enzymes play an essential role in follicular atresia formation and development, in which alkaline phosphatase inhibits follicular atresia $[16,19,24]$. Therefore, antioxidant enzymes such as superoxide dismutase, catalase (CAT), and glutathione peroxidase (GPx) play a role in the change of granulosa cells apoptosis to follicular atresia. Imbalanced levels of these enzymes and oxidants induce ROS production involved in atresia follicles development [25].

Interestingly, the results indicated that the follicular atresia of the treatment group (T2, T3, T4) presented a higher percentage and intensity of SOD expression than of the T1 group. The cassava leaves extract, vitamin C, and metronidazole might enhance the endogenous antioxidant enzyme activity (SOD). Besides, the repair process might still be ongoing. Thus, the remnants of atresia follicles were still present after a week of therapy. This process might need and take more time. Furthermore, the study revealed that SOD activity decreased significantly and correlated with the stage of follicular atresia development. An increase in the SOD activity indicates that the atresia stage obtains improvement or healing atresia $[22,25,26]$.

The decreased activity of antioxidant enzymes, either in the follicular fluid or granulosa cells, facilitates several ROS formations, which affects cellular integrity. The accumulation stimulates severe damage of cellular DNA, lipids, proteins, and other macromolecules resulting in cell apoptosis. Finally, they trigger follicular atresia as comprehensive granulosa cell apoptosis $[16,19]$.

Although the body produces SOD endogenously, the exogenous antioxidants and external factors affect its production process. Cassava leaves extract containing bioactive compounds might have antioxidant activity. Our previous study revealed that the active ingredients, such as vitamins $C, E$, polyphenols, and flavonoids, were identified in the cassava leaf extract [15]. The cassava leaves extract acting as an exogenous antioxidant might balance the excessive oxidants caused by $P$. gingivalis 
infection. Moreover, those compounds might enhance the SOD enzyme activity. Flavonoid, polyphenol, and vitamin C activate ROS-removing mechanism through electron transfer and ROSremoving enzyme induction, such as SOD [27-30]. Therefore, as an antibiotic, metronidazole alters the SOD enzyme activity by reducing $P$. gingivalis virulence and infection. Deprivation of bacterial virulence and infection affects the number of ROS and oxidative stress [31].

\section{CONCLUSION}

P. gingivalis and cassava leaves extract influenced SOD expression in the ovaries of the animal model. This study indicated that $P$. gingivalis infection affected follicular development. P. gingivalis might stimulate systemic inflammation and hormonal alteration. According to our preliminary study, P. gingivalis infection altered follicle-stimulating hormone and oestrogen, stimulating chronic systemic infection. This alteration and infection might be correlated to oxidative stress stimulation.
This study needed further exploration to describe and identify the stages of atresia follicle development and biochemical alteration of the follicle fluid.

\section{ACKNOWLEDGEMENT}

This research was supported by Universitas Jember Grant awarded to Zahreni Hamzah and her team. The authors wish to acknowledge the Faculty of Dentistry, Universitas Jember; the Faculty of Pharmacy, Universitas Jember; and Mr. Kaliawan for providing the facilities to carry out this research.

\section{DECLARATION OF INTEREST}

The authors report no conflict of interest. The authors alone are responsible for the content of this article.

\section{REFERENCES}

1. Ramadhani SA, Supriatna I, Karja NW, Winarto A. Pengendalian folikulogenesis ovarium dengan pemberian ekstrak biji kapas. Jurnal Sain Veteriner 2017; 35(1):71-80.

2. Sun $\mathrm{H}$, Gong TT, Jiang YT, Zhang S, Zhao YH, Wu QJ. Global, regional, and national prevalence and disabilityadjusted life-years for infertility in 195 countries and territories, 1990-2017: results from a global burden of disease study, 2017. Aging (Albany NY). 2019; 11(23):10952.

3. Dharmayanti AW, Kusumawardani B. Deoxypyridinoline and mineral levels in gingival crevicular fluid as disorder indicators of menopausal women with periodontal disease. Dental Journal (Majalah Kedokteran Gigi). 2017; 50(3):131-7.

4. Dharmayanti AW, Suhartini S, Kusumawardani B. Status kesehatan rongga mulut wanita suku osing. Medica Hospitalia: Journal of Clinical Medicine. 2019; 6(2):71-9.

5. Trenti A, Tedesco S, Boscaro C, Trevisi L, Bolego C, Cignarella A. Estrogen, angiogenesis, immunity and cell metabolism: solving the puzzle. Int J Mol Sci. 2018; 19(3):859.

6. Vieira AT, Castelo PM, Ribeiro DA, Ferreira CM. Influence of oral and gut microbiota in the health of menopausal women. Front Microbiol. 2017; 8:1884.

7. Udagawa S, Katagiri S, Maekawa S, Takeuchi Y, Komazaki R, Ohtsu A, Sasaki N, Shiba T, Watanabe K, Ishihara $\mathrm{K}$, Sato N. Effect of Porphyromonas gingivalis infection in the placenta and umbilical cord in pregnant mice with low birth weight. Acta Odontol Scand. 2018; 76(6):433-41.

8. Machado V, Escalda C, Proença L, Mendes JJ, Botelho J. Is there a bidirectional association between polycystic ovarian syndrome and periodontitis? A systematic review and meta-analysis. J Clin Med. 2020; 9(6):1961.

9. Penoni DC, Vettore MV, Torres SR, Farias ML, Leão AT. An investigation of the bidirectional link between osteoporosis and periodontitis. Arch Osteoporos. 2019; 14(1):94.

10. Bellanti F, Matteo M, Rollo T, De Rosario F, Greco P, Vendemiale G, Serviddio G. Sex hormones modulate circulating antioxidant enzymes: impact of estrogen therapy. Redox Biol. 2013; 1(1):340-6.

11. Bullon P, Cordero MD, Quiles JL, Morillo JM, del Carmen Ramirez-Tortosa M, Battino M. Mitochondrial dysfunction promoted by Porphyromonas gingivalis lipopolysaccharide as a possible link between cardiovascular disease and periodontitis. Free Radic Biol Med. 2011; 50(10):1336-43. 
12. Rao PS, Kalva S, Yerramilli A, Mamidi S. Free radicals and tissue damage: Role of antioxidants. Free Radicals and Antioxidants. 2011; 1(4):2-7.

13. Onopiuk B, Onopiuk P, Dąbrowska Z, Dąbrowska E, Pietruska M, \& Car H. Effect of metronidazole on the oxidoreductive processes in the submandibular and parotid glands in experimental research. Oxid Med Cell Longev. 2018; 2018:1-6.

14. Meilawaty Z. Efek ekstrak daun singkong (Manihot utilissima) terhadap ekspresi COX-2 pada monosit yang dipapar LPS E. coli (The effect of Manihot utilissima extracts on COX-2 expression of monocytes induced by LPS E. coli). Dental Journal (Majalah Kedokteran Gigi). 2013; 46(4):196-201.

15. Meilawaty Z, Shita AD, Kuncaraningtyas PL, Dharmayanti AW, Hamzah Z. Potensi ekstrak daun singkong (Manihot esculenta Crantz) terhadap ekspresi MMP-8 fibroblas gingiva pada model tikus dengan disfungsi ovarium dan periodontitis Potential of cassava (Manihot esculenta Crantz) leaf extract on the MMP-8 expression of gingival fibroblast in rats model with ovarian dysfunction and periodontitis. Jurnal Kedokteran Gigi Universitas Padjadjaran. 2020; 32(2):105-12.

16. Varghese $F$, Bukhari $A B$, Malhotra R, De A. IHC Profiler: an open source plugin for the quantitative evaluation and automated scoring of immunohistochemistry images of human tissue samples. PloS One. 2014; 9(5):e96801.

17. Devine PJ, Perreault SD, Luderer U. Roles of reactive oxygen species and antioxidants in ovarian toxicity. Biol Reprod. 2012; 86(2):27-1.

18. Bhardwaj JK, Sharma RK, Saraf P. Alterations in phosphatases and antioxidant enzymes'activity in follicular fluid and granulosa cells during follicular atresia in goat (Capra hircus) ovary. J Adv Zool. 2017; 38(2):15463.

19. Wang X, Li C, Wang Y, Li L, Han Z, Wang G. UFL1 Alleviates LPS-Induced Apoptosis by Regulating the NF-KB Signaling Pathway in Bovine Ovarian Granulosa Cells. Biomolecules. 2020; 10(2):260.

20. Da Kyung Yoo SH. Effect of lipopolysaccharide (LPS) exposure on the reproductive organs of immature female rats. Development \& Reproduction. 2016; 20(2):113.

21. Magata F. Lipopolysaccharide-induced mechanisms of ovarian dysfunction in cows with uterine inflammatory diseases. J Reprod Dev. 2020; 66(4):311-317.

22. Baerwald AR, Adams GP, Pierson RA. Ovarian antral folliculogenesis during the human menstrual cycle: a review. Hum Reprod Update. 2012; 18(1):73-91.

23. Matsuda F, Inoue N, Manabe N, Ohkura S. Follicular growth and atresia in mammalian ovaries: regulation by survival and death of granulosa cells. J Reprod Dev. 2012; 58(1):44-50.

24. Combelles CM, Holick EA, Paolella LJ, Walker DC, Wu Q. Profiling of superoxide dismutase isoenzymes in compartments of the developing bovine antral follicles. Reprod. 2010; 139(5):871-81.

25. Zalukhu ML, Phyma AR, Pinzon RT. Proses Menua, Stres Oksidatif, dan Peran Anti Oksidan. Cermin Dunia Kedokteran. 2016; 43(10):733-6.

26. Zeinalivand S, Hayati Roudbari N, Parivar K. Follicular growth and atresia and morphometric alteration of uterine tissue following letrozole administration in mature NMRI mice. Int J Basic Appl Med Sci. 2019; 5(2):103-10.

27. Procházková D, Boušová I, Wilhelmová N. Antioxidant and prooxidant properties of flavonoids. Fitoterapia. 2011; 82(4):513-523.

28. Dharmayanti AW, Dubey R, Dubey NK, Deng WP. Implant surface modification strategies through antibacterial and bioactive components. In Biopolymer-Based Formulations 2020 (pp. 647-673). Elsevier.

29. Louis XL, Thandapilly SJ, Kalt W, Vinqvist-Tymchuk M, Aloud BM, Raj P, Yu L, Le H, Netticadan T. Blueberry polyphenols prevent cardiomyocyte death by preventing calpain activation and oxidative stress. Food Funct. 2014; 5(8):1785-94.

30. Sadi G, Yılmaz Ö, Güray T. Effect of vitamin C and lipoic acid on streptozotocin-induced diabetes gene expression: mRNA and protein expressions of Cu-Zn SOD and catalase. Mol Cellular Biochem. 2008; 309(12):109-16.

31. Graziano TS, Closs P, Poppi T, Franco GC, Cortelli JR, Groppo FC, Cogo K. Catecholamines promote the expression of virulence and oxidative stress genes in P orphyromonas gingivalis. J Periodontal Res. 2014; 49(5):660-9. 


\section{Editorial History}

Date of Submission: 24 Nov 2020

Review \& Revision: 30 Nov 2020 - 7 June 2021

Accepted: 9 June 2021

Published: 23 July 2021

License Information: This work is licensed under a Creative Commons Attribution 